\title{
Identification and biotechnological characterization of Lactic Acid Bacteria Isolated from White Cheese Samples
}

\author{
Sumeyya Akbulut \\ Ataturk University: Ataturk Universitesi \\ Mustafa Ozkan Baltaci \\ Ataturk University: Ataturk Universitesi \\ Gulsah Adiguzel \\ Ataturk University: Ataturk Universitesi \\ Ahmet Adiguzel ( $\square$ adiguzel@atauni.edu.tr) \\ Ataturk University: Ataturk Universitesi https://orcid.org/0000-0001-8848-6647
}

Research Article

Keywords: Lactic acid bacteria, Bacteriocin, Molecular characterization, biotechnological enzymes

Posted Date: June 18th, 2021

DOI: https://doi.org/10.21203/rs.3.rs-630567/v1

License: (c) (i) This work is licensed under a Creative Commons Attribution 4.0 International License. Read Full License

Version of Record: A version of this preprint was published at Journal of Pure and Applied Microbiology on December 1st, 2022. See the published version at https://doi.org/10.22207/JPAM.16.4.66. 


\section{Abstract}

In this study, the isolation of lactic acid bacteria were carried out from approximately one hundred white cheese samples collected from different regions of Turkey. Subsequently, phenotypic and genotypic characterization of the isolates were performed. Finally, biotechnological enzyme and bacteriocin production potentials of the isolates were determined. As a result of the analysis, a total of fourty one bacteria were isolated and seventeen of them were found to be different species. The isolates generally grew at $4-6 \mathrm{pH}$ values, $0-8 \% \mathrm{NaCl}$ and $30-40{ }^{\circ} \mathrm{C}$. Genomic fingerprint profiles of the isolates were determined by using BOX-PCR. According to 16S rRNA sequence results, test strains belong to Lentilactobacillus kefiri, Levilactobacillus brevis, Lacticaseibacillus casei, Lacticaseibacillus paracasei, Pediococcus Iolii, Staphylococcus haemolyticus, Lysnibacillus sinduriensis, P. parvulus, Lactiplantibacillus paraplantarum, Staphylococcus hominis, Lactiplantibacillus plantarum, Enterococcus faecium, Micrococcus yunnanensis, Microbacterium paraoxydans and Micrococcus aloeverae species. Since the isolate coded MA56 is $96.41 \%$ similar to Lentilactobacillus buchneri, it is thought to be a new species. Also MA19, MA25, MA43 and MA47 were determined to have multi-enzyme production potential. MA43 was found to be the only isolate producing bacteriocin.

\section{Introduction}

Cheese is produced by coagulating the milk with the effect of a suitable proteolytic enzyme or organic acids. and processing, filtering, suppressing and maturing in various ways (Carafa et al. 2015; Domingos-Lopes et al. 2017). The unique taste and aroma of cheese is obtained by the addition of lactic acid bacteria to the culture. Lactic acid bacteria ( $\mathrm{LAB}$ ) are gram positive bacteria that produce lactic acid as the main product during the fermentation of carbohydrates (Alvarez-Sieiro et al. 2016; Varoquaux and Wiley 2017). They are non-spore-forming, anaerobic or microaerophilic and acid-tolerant organisms with rod or coccal cells (Agriopoulou et al. 2020; Ayeni et al. 2009; Shoukat 2020). LAB is a group of bacteria that consists of genus such as Streptococcus, Lactococcus, Pediococcus, Enterococcus, Lactobacillus is commonly found in dairy and fermented foods (Azam et al. 2017; Barbieri et al. 2019; Szutowska and Gwiazdowska 2021). There are many studies reporting the health benefits of fermented dairy products. Fermented foods typically contain microorganisms considered to be generally regarded as safe (GRAS), which can produce a range of beneficial by-products / metabolites such as antimicrobial peptides (e.g. bacteriocins), ethanol, organic acids, fatty acids, carbon dioxide (Macori and Cotter 2018; Marco et al. 2017). It is known that products resulting from LAB-induced fermentations have anti-cancer (Bindu and Lakshmidevi 2021), immunomodulatory (Qian et al. 2011), anti-gastritis (Rodriguez et al. 2009), Antihypertensive (Mallappa et al. 2021) and, anti-allergenic effects (Drywien et al. 2015). In addition, Mozaffarian et al. were reported that consuming LAB fermented foods had positive effects on weight (Chen et al. 2014; Mozaffarian et al. 2011). Other studies have shown that the consumption of fermented yogurt and dairy products can reduce the risk of developing cardiovascular disease (CVD) and type 2 diabetes mellitus (T2DM) (Eussen et al. 2016; Soedamah-Muthu et al. 2013). In addition, researchers reported that fermented milk and dairy products associated with LAB have hypocholesteremic (Lye et al. 2010) and anti-cancer properties (Kapila et al. 2007).

Besides the health aspect, LABs can also be the source of new species with enzymatic activities for biotecnological process (Mathur et al. 2020). Microbial enzymes are more preferred than other enzymes because they have high catalytic activity and efficiency. Major enzymes used in biotechnological processes include amylases, proteases, and lipases. LAB with amylase, lipase xylanases and protease activities have been reported in previous studies. (Adiguzel et al. 2019; Konkit and Kim 2016; Saez et al. 2018; Unban et al. 2017). Considering these properties, interest in lactic acid bacteria is increasing day by day and there are many LAB species with technological potential yet to be discovered. In the light of all this information, in this study, isolation, identification and molecular characterization of lactic acid bacteria from cheese samples collected from different regions (Erzurum, Van, Konya, Karaman and Kars) of Turkey were carried out. Later, biotechnologically important enzyme and bacteriocin production potentials of the isolates were determined.

\section{Material And Methods}

\section{Sampling and lactic acid bacteria isolation}

A total of one hundred Cow cheese samples taken from markets in different regions of Turkey were brought to the laboratory under aseptic conditions and kept at $+4^{\circ} \mathrm{C}$ until they were studied. $225 \mathrm{ml}$ of sterile physiological water $(0.9 \% \mathrm{NaCl})$ was added to $25 \mathrm{~g}$ cheese sample and homogenization process was carried out and dilution series $\left(10^{0}-10^{-7}\right)$ were prepared (Luiz et al. 2017). The dilution liquids were spread on MRS and M17 Agar media and incubated at $35^{\circ} \mathrm{C}$ for 48 hours. After the incubation, isolates were stored at $-86^{\circ} \mathrm{C}$ in a stock medium containing $15 \%$ glycerol (Kirmaci et al. 2016 ).

\section{Phenotypic Characterization}

To determine phenotypic characterization, test strains were grown in MRS and $\mathrm{M} 17$ medium at different temperatures $15^{\circ} \mathrm{C}$ to $50^{\circ} \mathrm{C}$ (with $5^{\circ} \mathrm{C}$ intervals) for up to $72 \mathrm{~h}$. The $\mathrm{pH}$ ranges were analyzed in MRS and M17 at pH 3.0-11.0 (1 pH unit intervals), Tolerance of NaCl was determined using MRS and M17 supplemented with $0-12 \% \mathrm{NaCl}$ (at intervals of $1.0 \%$ ) for $72 \mathrm{~h}$. All experiment were tested in triplicate and growth was measured at OD600 nm (Baltaci et al. 2020). Gram-staining of test strains was performed according to method of Gerhardt et al (Gerhardt et al. 1981). Catalase activity was performed by the production of bubbles of a drop of $3 \% \mathrm{H}_{2} \mathrm{O}_{2}(\mathrm{v} / \mathrm{v})$. Oxidase reagent (Sigma) was used for testing oxidase activity (Adiguzel et al. 2020). Biochemical characterization of isolates were conducted using API 50CHL test (Anekella and Perez-Diaz 2020).

\section{Genotypic Characterization}


Genomic DNA isolation were performed according to the Promega WizardR Genomic DNA Purification Kit (A2360) protocol. 16S rRNA region was amplified using 27F (5'-AGAGTTTGATCCTGGCTCAG-3') and 1492R (5'-GGTTACCTTGTTACGACTT-3') primers (Baltaci and Adiguzel 2016). 30 $\mu \mathrm{L}$ volume of PCR mixture containing, $13.1 \mu \mathrm{lddH} 2 \mathrm{O}, 3 \mu \mathrm{l}$ 10X PCR buffer, $1.8 \mu \mathrm{l} \mathrm{MgCl} 2,1.2 \mu \mathrm{l} \mathrm{DMSO}, 0.6 \mu \mathrm{dNTP}, 3 \mu \mathrm{l}(5 \mu \mathrm{M})$ forward primer $(27 \mathrm{~F}), 3 \mu \mathrm{l}$ $(5 \mu \mathrm{M})$ reverse primer (1492R), $0.3 \mu \mathrm{l} \mathrm{Taq} \mathrm{DNA} \mathrm{polymerase} \mathrm{and} 4 \mu \mathrm{l}$ template DNA. The amplified fragments were cloned into Escherichia coli JM101 strain with the pGEM-T Easy Cloning Vector (Promega, Southampton, UK) according to the instructions of the manufacturer. After the cloning, plasmid isolation was performed by selecting colonies that gave the positive result, and the sequence analysis was made by the Macrogen Company (Netherlands). The 16S rRNA obtained was compared with the other bacterial series in GenBank and EzTaxon (http://blast.ncbi.nlm.nih and http://www.eztaxon.org), similarity rate between them was determined and GenBank accession numbers were received (Baltaci et al. 2017).

rep-PCR

The rep-PCR reactions were carried out in a Sensequest Thermal Cycler (Göttingen, Germany) using BOXAIR primer (5'-CTACGGCAAGGCGACGCTGACG3'), PCR mixtures contained: $5 \mu \mathrm{l}$ Gitschier Buffer, $12.7 \mu \mathrm{ddd}_{2} \mathrm{O}, 2.5 \mu \mathrm{l}$ dimethyl sulfoxide, $1.25 \mu \mathrm{l}$ bovine serum albümin, $1.25 \mu \mathrm{dNTP}, 4 \mu \mathrm{l}$ primer, 0.3 $\mu \mathrm{l}$ Taq DNA polymerase and $3 \mu \mathrm{l}$ template DNA. Pcr Cycles were; initial denaturation at $94^{\circ} \mathrm{C}$ for 7 min., 36 cycles of $1 \mathrm{~min}$. at $94^{\circ} \mathrm{C}, 1 \mathrm{~min}$. at $45^{\circ} \mathrm{C}, 8$ min. at $65^{\circ} \mathrm{C}$. Final extention at $65^{\circ} \mathrm{C}$ for $16 \mathrm{~min}$. At the end of PCR, samples were run in $1 \%$ agarose gel for 90 minutes (Saez et al. 2017 ).

\section{Determination of Industrial Enzyme Production Potentials of Isolates}

\section{Lipase}

To test lipase enzyme production, isolates were inoculated into tributyrin agar medium containing $1 \%$ tributyrin (glycerol tributyrate) and incubated at $35^{\circ} \mathrm{C}$ for $48 \mathrm{~h}$. Isolates with clear zone were considered positive for lipase (Linares-Morales et al. 2020).

\section{Amylase}

Test strains were streaked on plates containing MRS agar with $1 \%$ starch instead glucose that were incubated at $35^{\circ} \mathrm{C}$ for $48 \mathrm{~h}$. Then, petri dishes were treated with Lugol's solution. Isolates showing clear zones were evaluated as amylase positive (Padmavathi et al. 2018).

\section{Protease}

To test whether isolates were producers of protease enzymes inoculated into MRS agar and containing $1 \%$ Skim Milk Powder and incubated at $35^{\circ} \mathrm{C}$ for 48 hours. Isolates with clear zone were considered positive for protease (Linares-Morales et al. 2020).

\section{Xylanase}

Isolates were inoculated into medium containing xylan $\left(10 \mathrm{gL}^{-1}\right), \mathrm{NaNO}_{3}\left(1.2 \mathrm{gL}^{-1}\right), \mathrm{KH}_{2} \mathrm{PO}_{4}\left(13 \mathrm{gL}^{-1}\right), \mathrm{K}_{2} \mathrm{HPO}_{4}\left(6 \mathrm{gL}^{-1}\right), \mathrm{CaCl}_{2}\left(0.05 \mathrm{gL}^{-1}\right), \mathrm{MgSO}_{4}$ $\left(0.01 \mathrm{gL}^{-1}\right), \mathrm{ZnSO}_{4}\left(0.001 \mathrm{gL}^{-1}\right)$ and agar $\left(15 \mathrm{gL}^{-1}\right)$ incubated at $35^{\circ} \mathrm{C}$ for 48 hours. After incubation, the plates were stained for 20 min with $0.1 \%$ congo red and washed with $1 \mathrm{M} \mathrm{NaCl}$. Isolates with orange colored zones were evaluated xylanase as positive (Adiguzel et al. 2019).

\section{Determination of Bacteriocin Production Potentials}

After determination of isolates species, The presence of related bacteriocin genes were investigated. For this purpose, PCR analyzes were performed using primers specific to each bacteriocin gene (Chiorean et al. 2018). The 16 S PCR cycle given above was performed by changing anneling temperatures of bacteriocin primers.

\section{Detection of Antibacterial Activity}

For detection of antimicrobial activity, disc diffusion assay was used. Pathogenic bacteria were spread on the surfaces of Mueller Hinton agar media. Overnight cultures, on MRS medium, of the strains to be tested were centrifuged and cell free supernatant was loaded on discs. The plates were incubated at $37^{\circ} \mathrm{C}$ for $24 \mathrm{~h}$. The antagonistic effects of the test strains were determined by measuring the zone diameters (Mezaini et al. 2009). The target test strains used in this study are Escherichia coli 0157:H7 (ATCC 43888), Salmonella typhimurium (ATCC 14028), Serratia marcescens (ATCC 810), Pseudomonas aeruginosa (ATCC 9027), Streptococcus pyogenes (ATCC 12344), Klebsiella pneumoniae (ATCC 13883), Listeria monocytogenes (ATCC 7644), Staphylococcus epidermidis (ATCC 12228), Shigella dysenteriae (ATCC 13313) and Staphylococcus aureus (ATCC 6538).

\section{Results And Discussion}

\section{Isolation of $\mathrm{LAB}$}

In the study, a total of 41 bacteria isolated from cheese samples obtained from Erzurum Kars, Karaman, Konya and Van provinces for the isolation of lactic acid bacteria and stock cultures were prepared. Since seventeen of the isolated bacteria belonged to different species, the study was continued with these isolates.

\section{Phenotypic Characterization}


According to conventional analysis; all isoates were gram positive, catalase and oxidase negative and showed cocci or bacil cell morphology. Generally isolates grow at $4-6 \mathrm{pH}$ values, $0-8 \% \mathrm{NaCl}$ and $30-40^{\circ} \mathrm{C}$. Similarly, Kuikui et al., was determined isolated lactic acid bacteria can usually grow at $35-$ $45^{\circ} \mathrm{C}$ at $\mathrm{pH} 3$ and $6.5 \% \mathrm{NaCl}$ (Ni et al. 2015). Interestingly, it has been found that MA7 strain can thrive in wide range of pH and salt concentrations such as $\mathrm{pH}: 2-11$ and $0-10 \% \mathrm{NaCl}$. So, MA7 can be suitable for many biotechnological processes. Detailed phenotypic characteristics and API test results are given in the Table 1. 
Table 1

Phenotypic properties of isolates 1: MA4, 2: MA7, 3: MA10, 4: MA12, 5: MA19, 6: MA25, 7: MA 27, 8: MA28, 9: MA31, 10: MA33, 11: MA34, 12: MA35, 13: MA39, 14: MA43, 15: MA47, 16: MA55, 17: MA56

\begin{tabular}{|c|c|c|c|c|c|c|c|c|c|c|c|c|c|c|c|c|c|}
\hline & 1 & 2 & 3 & 4 & 5 & 6 & 7 & 8 & 9 & 10 & 11 & 12 & 13 & 14 & 15 & 16 & 17 \\
\hline $\mathrm{pH}$ & $4-6$ & $\begin{array}{l}2- \\
11\end{array}$ & $4-6$ & $2-8$ & $3-6$ & $4-6$ & $4-7$ & $4-5$ & $4-6$ & $4-6$ & $4-6$ & $4-6$ & $5-7$ & $4-6$ & $3-6$ & $4-6$ & $2-8$ \\
\hline $\mathrm{NaCl}$ & $0-9$ & $\begin{array}{l}0- \\
10\end{array}$ & $0-9$ & $0-8$ & $4-6$ & $0-6$ & $0-8$ & $\begin{array}{l}0- \\
11\end{array}$ & $0-8$ & $0-6$ & $0-8$ & $0-8$ & $0-8$ & $0-5$ & $0-8$ & $\begin{array}{l}0- \\
10\end{array}$ & $0-8$ \\
\hline Temperature & $\begin{array}{l}30- \\
40\end{array}$ & $\begin{array}{l}30- \\
40\end{array}$ & $\begin{array}{l}15- \\
45\end{array}$ & $\begin{array}{l}30- \\
40\end{array}$ & $\begin{array}{l}30- \\
40\end{array}$ & $\begin{array}{l}30- \\
40\end{array}$ & $\begin{array}{l}15- \\
45\end{array}$ & $\begin{array}{l}15- \\
45\end{array}$ & $\begin{array}{l}15- \\
45\end{array}$ & $\begin{array}{l}30- \\
40\end{array}$ & $\begin{array}{l}30- \\
40\end{array}$ & $\begin{array}{l}15- \\
45\end{array}$ & $\begin{array}{l}30- \\
40\end{array}$ & $\begin{array}{l}30- \\
40\end{array}$ & $\begin{array}{l}30- \\
40\end{array}$ & $\begin{array}{l}30- \\
40\end{array}$ & $\begin{array}{l}30- \\
40\end{array}$ \\
\hline Morphology & Bacil & Bacil & Bacil & Bacil & Coc & Coc & Coc & Bacil & $\mathrm{Coc}$ & Coc & Bacil & Coc & Coc & Bacil & $\mathrm{Coc}$ & Coc & Bacil \\
\hline Oksidase & - & - & - & - & - & - & - & - & - & - & - & - & - & - & - & - & - \\
\hline Catalase & - & - & - & - & - & - & - & - & - & - & - & - & - & - & - & - & - \\
\hline L-Arabinose & + & - & + & - & - & - & + & + & - & - & - & + & - & - & - & - & + \\
\hline Ribose & - & + & + & - & - & - & + & + & $\mathrm{d}$ & - & + & + & - & + & - & - & + \\
\hline Xylose & - & - & - & - & - & - & - & + & - & - & - & + & - & - & - & - & + \\
\hline Adonitol & - & + & - & - & - & - & - & - & - & - & - & - & - & - & - & - & - \\
\hline Galactose & - & + & + & - & - & - & + & + & + & + & + & + & + & + & - & + & + \\
\hline D-Glucose & - & + & + & - & - & - & + & + & + & + & + & + & + & + & - & + & + \\
\hline D-Fructose & - & + & + & - & - & - & + & + & - & + & + & + & + & + & - & + & + \\
\hline D-Mannose & - & + & + & - & - & - & + & - & - & - & + & + & $d$ & + & - & + & - \\
\hline Rhamnose & - & - & + & - & - & - & - & - & - & - & - & $d$ & - & - & - & - & - \\
\hline Dulcitol & - & - & - & - & - & - & - & - & - & - & + & - & - & - & - & - & - \\
\hline Mannitol & - & + & + & - & - & - & - & - & - & - & + & - & - & + & - & - & - \\
\hline Sorbitol & - & + & + & - & - & - & - & - & - & - & + & - & - & - & - & - & - \\
\hline Met-D-Gluc. & - & - & + & - & - & - & - & d & - & - & - & - & - & - & - & - & + \\
\hline NAG & - & + & + & - & - & - & + & $d$ & $d$ & + & + & + & - & + & - & + & + \\
\hline Amygdaline & - & + & + & - & - & - & + & - & - & - & - & - & - & + & - & - & - \\
\hline Arbutine & - & + & + & - & - & - & + & - & - & - & + & - & - & + & - & - & - \\
\hline Esculine & $d$ & + & - & + & - & - & + & - & - & - & - & + & - & + & - & + & - \\
\hline Salicine & - & + & + & - & - & - & + & - & - & - & + & $d$ & $d$ & + & - & $d$ & - \\
\hline Cellobiose & - & + & + & - & - & - & + & - & - & - & + & + & - & + & - & + & - \\
\hline Maltose & - & $\mathrm{d}$ & + & - & - & - & + & + & + & + & + & - & + & + & - & - & + \\
\hline Lactose & - & + & + & - & - & - & + & + & + & + & - & + & + & + & - & + & + \\
\hline Melibiose & - & - & - & - & + & + & - & + & - & - & - & - & - & + & + & - & + \\
\hline Saccharose & - & $\mathrm{d}$ & + & - & - & - & - & - & + & d & - & - & + & + & - & - & - \\
\hline Trehalose & - & + & + & - & - & - & + & - & + & + & + & + & + & + & - & $d$ & + \\
\hline Melezitose & - & + & + & - & - & - & - & - & - & - & + & - & $d$ & + & - & - & - \\
\hline D-Raffinose & - & - & - & - & - & - & - & - & - & - & - & - & - & - & - & - & + \\
\hline Gentiobiose & - & - & + & - & - & - & + & - & - & - & + & + & - & + & - & + & - \\
\hline D-Turanose & - & + & - & - & - & - & - & - & $d$ & $d$ & + & - & $d$ & - & - & - & - \\
\hline D-Tagatose & - & + & - & - & - & - & - & - & - & - & + & $d$ & - & - & - & + & - \\
\hline D-Arabitol & - & - & + & - & - & - & - & - & - & - & - & - & - & $\mathrm{d}$ & - & - & - \\
\hline
\end{tabular}




\begin{tabular}{|c|c|c|c|c|c|c|c|c|c|c|c|c|c|c|c|c|c|}
\hline & 1 & 2 & 3 & 4 & 5 & 6 & 7 & 8 & 9 & 10 & 11 & 12 & 13 & 14 & 15 & 16 & 17 \\
\hline L-Arabitol & - & - & - & - & - & - & - & - & - & - & - & - & - & - & - & - & - \\
\hline
\end{tabular}

\section{Genotypic Characterization}

16S rRNA sequence analysis is used as a powerful tool in determining the prokaryotic diversity in almost every environment (Edgar 2018a; MartinezPorchas et al. 2017). So, we performed molecular identification of lactic acid bacteria isolated from cheese samples based on $16 \mathrm{~S}$ rRNA sequence. Except for MA56, all isolates are $99 \%$ similar to related standard type strains. MA56 has $96.41 \%$ similarity with Lentilactobacillus buchneri DSM 20057. According to general acceptance, the 16 S rRNA gene sequence similarity ratio below $97 \%$ is a new species indicator of the isolate. In recent years, it has been reported that this rate is $98.2 \%-99 \%$ and that the whole genome sequence and DNA:DNA hybridization is required in addition to the $16 \mathrm{~S}$ rRNA gene sequence (Edgar 2018b; Meier-Kolthoff et al. 2013). According to this information, MA56 might be a novel species belonging to the genus Lentilactobacillus. It is thought that MA56 will be added to the literature as a novel species as a result of the whole genome sequence analysis in future studies. Detailed sequence results of the isolates and related species are given in Table 2. Also, 16S rRNA gene based phylogenetic tree is shown in Fig. 1.

Table 2

Related species and similarity rates of isolates according to 16S rRNA sequence analysis

\begin{tabular}{|c|c|c|c|c|}
\hline Isolate Code & Product size (bp) & Related species & Similarity rate (\%) & Genbank No. \\
\hline MA 4 & 1535 & Lentilactobacillus kefiri & 99 & KY425772 \\
\hline MA 7 & 813 & Lacticaseibacillus casei & 99 & KY425775 \\
\hline MA 10 & 1528 & Lactiplantibacillus paraplantarum & 99 & KY425790 \\
\hline MA 12 & 1515 & Lysinibacillus sindurienssis & 99 & KY425788 \\
\hline MA 19 & 1484 & Micrococcus yunnanensis & 99 & KY425784 \\
\hline MA 25 & 1486 & Microbacterium paraoxydans & 99 & KY425786 \\
\hline MA 27 & 1387 & Enterococcus faecium & 99 & KY425810 \\
\hline MA 28 & 1527 & Levilactobacillus brevis & 99 & KY425773 \\
\hline MA 31 & 1512 & Staphylococcus haemolyticus & 99 & KY425785 \\
\hline MA 33 & 885 & Staphylococcus hominis & 99 & KY425791 \\
\hline MA 34 & 1531 & Lacticaseibacillus paracasei subsp. paracesi & 99 & KY425778 \\
\hline MA 35 & 1538 & Pediococcus lolii & 99 & KY425782 \\
\hline MA 39 & 1488 & Rothia dentocariosa & 99 & KY425811 \\
\hline MA 43 & 1528 & Lactiplantibacillus plantarum subsp. plantarum & 99 & KY425796 \\
\hline MA 47 & 1462 & Micrococcus aloeverae & 99 & KY425780 \\
\hline MA 55 & 1539 & Pediococcus parvulus & 99 & KY425789 \\
\hline MA 56 & 1491 & Lentilactobacillus buchneri & 96 & KY425792 \\
\hline
\end{tabular}

Previous studies have reported that rep-PCR is an easy method that can be used to classify bacteria. Mohammed et al. used BOX-PCR analysis to characterize lactic acid bacteria isolated from traditional milk samples in their study (Mohammed et al. 2009). We also performed genomic fingerprint analysis of isolates using BOX-PCR in this study. While 12 polymorphic bands were observed in some of the test strains, it was observed that there was 1 band in some isolates Fig. 2. It was observed that the BOX-PCR was not sufficient to clasify the all LAB.

\section{Determination of Biotechnological Enzyme Production Potentials of Isolates}

The potential of isolates to produce amylase, lipase, protease and xylanase enzymes, which are biotechnologically important, were determined. As a result of analysis one strains have xylanase and lipase activity, five strains with amylase activity, and ten strains with protease activity were observed (Table 3). Also petri images of some isolates are given in Fig. 3. Matthews et al. investigated the enzyme production potential of lactic acid bacteria and determined that especially Lactobacillus and Pediococcus species are important producers of lipase, cellulase and xylanase enzymes. In another study, Konkit and Kim examined that Lactoccocus chungangensis produces amylase, proteinase, and lipase enzymes (Konkit and Kim 2016). 
Table 3

Screening Industrial Enzyme Profiles of Isolates

\begin{tabular}{|c|c|c|c|c|c|}
\hline Isolate Code & Related species & Amylase & Lipase & Protease & Xylanase \\
\hline MA4 & Lentilactobacillus kefiri & - & - & ++ & - \\
\hline MA7 & Lacticaseibacillus casei & - & - & ++ & - \\
\hline MA10 & Lactiplantibacillus paraplantarum & - & - & - & - \\
\hline MA12 & Lysinibacillus sinduriensis & - & - & ++ & - \\
\hline MA19 & Micrococcus yunnanensis & ++ & - & ++ & - \\
\hline MA25 & Microbacterium paraoxydans & + & + & + & - \\
\hline MA28 & Levilactobacillus brevis & - & - & ++ & - \\
\hline MA31 & Staphylococcus haemolyticus & - & - & - & - \\
\hline MA33 & Staphylococcus hominis & - & - & ++ & - \\
\hline MA34 & Lactiplantibacillus paracasei subsp. paracesi & - & - & - & - \\
\hline MA35 & Pediococcus lolii & + & - & - & - \\
\hline MA39 & Rothia dentocariosa & - & - & - & - \\
\hline MA43 & Lactiplantibacillus plantarum subsp. plantarum & + & + & ++ & - \\
\hline MA47 & Micrococcus aloeverae & - & - & ++ & + \\
\hline MA55 & Pediococcus parvulus & + & - & - & - \\
\hline MA56 & Lentilactobacillus buchneri & - & - & ++ & - \\
\hline
\end{tabular}

Table 4

The result of disc diffusion test. The diameter of inhibition zone of MA43.

\begin{tabular}{|ll|}
\hline Pathogens & MA43 \\
\hline Serratia marcescens ATCC 810 & $5 \pm 0.4$ \\
\hline Shigella dysenteriae ATCC 13313 & $12 \pm 1.3$ \\
\hline Klebsiella pneumoniae ATCC 13883 & $12 \pm 0.8$ \\
\hline Streptococcus pyogenes ATCC 12344 & $10 \pm 0.4$ \\
\hline Staphylococcus epidermidis ATCC 12228 & $9 \pm 0.3$ \\
\hline Staphylococcus aureus ATCC 6538 & $12 \pm 0.8$ \\
\hline Pseudomonas aeruginosa ATCC 9027 & $16 \pm 1.1$ \\
\hline Salmonella typhimurium ATCC 14028 & $7 \pm 0.6$ \\
\hline Listeria monocytogenes ATCC 7644 & $9 \pm 0.7$ \\
\hline Escherichia coli O157:H7 ATCC 43888 & $19 \pm 0.5$ \\
\hline The measures of the inhibition zone are expressed in mm. \\
\hline
\end{tabular}

There are many studies in the literature in which enzymes obtained from lactic acid bacteria are used in biotechnological processes. For example, The xylanase enzyme purified from Pedioccus acidilactici was applied in clarification of fruit juices (Adiguzel et al. 2019). In another study, it was reported that the protease enzyme obtained from Lactobacillus plantarum had an antimicrobial effect on pathogenic microorganisms (Lin and Pan 2019). So, in this study, isolates coded MA19, MA25, MA43 and MA47 were determined to have multi-enzyme production potential (Table 3) and these isolates are attractive for biotechnological processes, because they have more than one enzyme activity.

\section{Determination of Bacteriocin Production Potential}

Whether the isolates produced bacteriocin was determined using specific bacteriocin primers with PCR. As a result of the PCR analysis, it was determined that only the MA43 coded isolate produced bacteriocin. The gel image of plantaricin belonging to MA43 and Lactobacillus plantarum ATCC 8014 are shown in Fig. 4. 
After it was determined that MA43 has bacteriosin gene, its effect against pathogenic bacteria was investigated. It has been determined that MA43 has a highest antagonistic effect against Escherichia coli 0157:H7 ATCC 43888 and Pseudomonas aeruginosa ATCC 9027. Previous studies have also reported that Lactobacillus plantarum has an antimicrobial effect against various pathogens (Layus et al. 2020; Wang et al. 2017). In this respect, MA43 has an antagonistic effect against foodborne pathogens shows that it can use food preservatives.

\section{Conclusions}

With this study, it was determined that the white cheese samples have a very wide microflora. 16S rRNA sequence similarity to the closest species of the MA56 was determined as $96.41 \%$. This isolate is highly likely to be a novel species of lactic acid bacteria. MA43 not only has amylase, lipase and protease activity but also produces bacteriosin makes it unique for biotechnological processes. In addition, this study leads to new studies for MA56 and MA43.

\section{Declarations}

\section{Declaration of competing interest}

The authors declare that they have no known competing financial interests or personal relationships that could have appeared to influence the work reported in this paper.

\section{Acknowledgements}

Not applicable.

\section{References}

1. Adiguzel A, Ay H, Baltaci MO, Akbulut S, Albayrak S, Omeroglu MA (2020) Genome-based classification of Calidifontibacillus erzurumensis gen. nov., sp. nov., isolated from a hot spring in Turkey, with reclassification of Bacillus azotoformans as Calidifontibacillus azotoformans comb. nov. and Bacillus oryziterrae as Calidifontibacillus oryziterrae comb. nov. Int J Syst Evol Microbiol 70(12):6418-6427. doi:10.1099/ijsem.0.004549

2. Adiguzel G, Faiz O, Sisecioglu M et al (2019) A novel endo-beta-1,4-xylanase from Pediococcus acidilactici GC25; purification, characterization and application in clarification of fruit juices. Int J Biol Macromol 129:571-578. doi:10.1016/j.ijbiomac.2019.02.054

3. Agriopoulou S, Stamatelopoulou E, Sachadyn-Krol M, Varzakas T (2020) Lactic Acid Bacteria as Antibacterial Agents to Extend the Shelf Life of Fresh and Minimally Processed Fruits and Vegetables: Quality and Safety Aspects. Microorganisms 8(6) doi:10.3390/microorganisms8060952

4. Alvarez-Sieiro P, Montalban-Lopez M, Mu DD, Kuipers OP (2016) Bacteriocins of lactic acid bacteria: extending the family. Appl Microbiol Biotechnol 100(7):2939-2951. doi:10.1007/s00253-016-7343-9

5. Anekella K, Perez-Diaz IM (2020) Characterization of robust Lactobacillus plantarum and Lactobacillus pentosus starter cultures for environmentally friendly low-salt cucumber fermentations. J Food Sci 85(10):3487-3497. doi:10.1111/1750-3841.15416

6. Ayeni FA, Adeniyi BA, Ogunbanwo ST et al (2009) Inhibition of uropathogens by lactic acid bacteria isolated from dairy foods and cow's intestine in western Nigeria. Arch Microbiol 191(8):639-648. doi:10.1007/s00203-009-0492-9

7. Azam M, Mohsin M, ljaz H et al (2017) Lactic acid bacteria in traditional fermented Asian foods. Pak J Pharm Sci 30(5):1803-1814

8. Baltaci MO, Adiguzel A (2016) Isolation, Identification and Molecular Characterization of Cellulolytic Bacteria from Rumen Samples collected from Erzurum Slaughter House, Turkey. Research Journal of Biotechnology 11(2):32-38

9. Baltaci MO, Ay H, Akbulut S et al (2020) Bacillus pasinlerensis sp. nov., a thermophilic bacterium isolated from a hot spring in Turkey. Int J Syst Evol Microbiol 70(6):3865-3871. doi:10.1099/ijsem.0.004246

10. Baltaci MO, Genc B, Arslan S, Adiguzel G, Adiguzel A (2017) Isolation and Characterization of Thermophilic Bacteria from Geothermal Areas in Turkey and Preliminary Research on Biotechnologically Important Enzyme Production. Geomicrobiol J 34(1):53-62. doi:10.1080/01490451.2015.1137662

11. Barbieri F, Montanari C, Gardini F, Tabanelli G (2019) Biogenic Amine Production by Lactic Acid Bacteria: A Review. Foods 8(1) doi:10.3390/foods 8010017

12. Bindu A, Lakshmidevi N (2021) Identification and in vitro evaluation of probiotic attributes of lactic acid bacteria isolated from fermented food sources. Arch Microbiol 203(2):579-595. doi:10.1007/s00203-020-02037-0

13. Carafa I, Nardin T, Larcher R, Viola R, Tuohy K, Franciosi E (2015) Identification and characterization of wild lactobacilli and pediococci from spontaneously fermented Mountain cheese. Food Microbiol 48:123-132. doi:10.1016/j.fm.2014.12.003

14. Chen M, Sun Q, Giovannucci E et al (2014) Dairy consumption and risk of type 2 diabetes: 3 cohorts of US adults and an updated meta-analysis. BMC Med 12:215. doi:10.1186/s12916-014-0215-1

15. Chiorean S, Vederas JC, van Belkum MJ (2018) Identification and Heterologous Expression of the sec-Dependent Bacteriocin Faerocin MK from Enterococcus faecium M3K31. Probiotics Antimicrobial Proteins 10(2):142-147. doi:10.1007/s12602-017-9374-7

Page $8 / 12$ 
16. Domingos-Lopes MFP, Stanton C, Ross PR, Dapkevicius MLE, Silva CCG (2017) Genetic diversity, safety and technological characterization of lactic acid bacteria isolated from artisanal Pico cheese. Food Microbiol 63:178-190. doi:10.1016/j.fm.2016.11.014

17. Drywien M, Frackiewicz J, Gornicka M, Gadek J, Jalosinska M (2015) Effect of probiotic and storage time of thiamine and riboflavin content in the milk drinks fermented by Lactobacillus casei KNE-1. Rocz Panstw Zakl Hig 66(4):373-377

18. Edgar RC (2018a) Accuracy of taxonomy prediction for 16S rRNA and fungal ITS sequences. PeerJ 6:e4652. doi:10.7717/peerj.4652

19. Edgar RC (2018b) Updating the $97 \%$ identity threshold for 16 S ribosomal RNA OTUs. Bioinformatics 34(14):2371-2375. doi:10.1093/bioinformatics/bty113

20. Eussen SJ, van Dongen MC, Wijckmans N et al (2016) Consumption of dairy foods in relation to impaired glucose metabolism and type 2 diabetes mellitus: the Maastricht Study. Br J Nutr 115(8):1453-1461. doi:10.1017/S0007114516000313

21. Gerhardt P, Murray R, Costilow RN et al (1981) Manual of methods for general bacteriology

22. Kapila S, Sinha PR, Singh S (2007) Influence of feeding fermented milk and non-fermented milk containing Lactobacillus casei on immune response in mice. Food Agricultural Immunology 18(1):75-82. doi:10.1080/09540100701317618

23. Kirmaci HA, Ozer BH, Akcelik M, Akcelik N (2016) Identification and characterisation of lactic acid bacteria isolated from traditional Urfa cheese. Int J Dairy Technol 69(2):301-307. doi:10.1111/1471-0307.12260

24. Konkit M, Kim W (2016) Activities of amylase, proteinase, and lipase enzymes from Lactococcus chungangensis and its application in dairy products. J Dairy Sci 99(7):4999-5007. doi:10.3168/jds.2016-11002

25. Layus BI, Gerez CL, Rodriguez AV (2020) Antibacterial Activity of Lactobacillus plantarum CRL 759 Against Methicillin-Resistant Staphylococcus aureus and Pseudomonas aeruginosa. Arab J Sci Eng 45(6):4503-4510. doi:10.1007/s13369-020-04491-w

26. Lin TH, Pan TM (2019) Characterization of an antimicrobial substance produced by Lactobacillus plantarum NTU 102 . J Microbiol Immunol Infect 52(3):409-417. doi:10.1016/j.jmii.2017.08.003

27. Linares-Morales JR, Cuellar-Nevarez GE, Rivera-Chavira BE, Gutierrez-Mendez N, Perez-Vega SB, Nevarez-Moorillon GV (2020) Selection of Lactic Acid Bacteria Isolated from Fresh Fruits and Vegetables Based on Their Antimicrobial and Enzymatic Activities. Foods 9(10) doi:10.3390/foods9101399

28. Luiz LMP, Castro RD, Sandes SHC et al (2017) Isolation and identification of lactic acid bacteria from Brazilian Minas artisanal cheese. CytaJournal of Food 15(1):125-128. doi:10.1080/19476337.2016.1219392

29. Lye HS, Rahmat-Ali GR, Liong MT (2010) Mechanisms of cholesterol removal by lactobacilli under conditions that mimic the human gastrointestinal tract. Int Dairy J 20(3):169-175. doi:10.1016/j.idairyj.2009.10.003

30. Macori G, Cotter PD (2018) Novel insights into the microbiology of fermented dairy foods. Curr Opin Biotechnol 49:172-178. doi:10.1016/j.copbio.2017.09.002

31. Mallappa RH, Balasubramaniam C, Nataraj BH et al (2021) Microbial diversity and functionality of traditional fermented milk products of India: Current scenario and future perspectives. Int Dairy J 114 doi:10.1016/j.idairyj.2020.104941

32. Marco ML, Heeney D, Binda S et al (2017) Health benefits of fermented foods: microbiota and beyond. Curr Opin Biotechnol 44:94-102. doi:10.1016/j.copbio.2016.11.010

33. Martinez-Porchas M, Villalpando-Canchola E, Ortiz Suarez LE, Vargas-Albores F (2017) How conserved are the conserved 16S-rRNA. regions? PeerJ 5:e3036. doi:10.7717/peerj.3036

34. Mathur H, Beresford TP, Cotter PD (2020) Health Benefits of Lactic Acid Bacteria (LAB) Fermentates. Nutrients 12(6) doi:10.3390/nu12061679

35. Meier-Kolthoff JP, Goker M, Sproer C, Klenk HP (2013) When should a DDH experiment be mandatory in microbial taxonomy? Arch Microbiol 195(6):413-418. doi:10.1007/s00203-013-0888-4

36. Mezaini A, Chihib NE, Bouras AD, Nedjar-Arroume N, Hornez JP (2009) Antibacterial activity of some lactic acid bacteria isolated from an Algerian dairy product. J Environ Public Health 2009:678495. doi:10.1155/2009/678495

37. Mohammed M, Abd El-Aziz H, Omran N, Anwar S, Awad S, El-Soda M (2009) Rep-PCR characterization and biochemical selection of lactic acid bacteria isolated from the Delta area of Egypt. Int J Food Microbiol 128(3):417-423. doi:10.1016/j.ijfoodmicro.2008.09.022

38. Mozaffarian D, Hao T, Rimm EB, Willett WC, Hu FB (2011) Changes in diet and lifestyle and long-term weight gain in women and men. N Engl J Med 364(25):2392-2404. doi:10.1056/NEJMoa1014296

39. Ni KK, Wang YP, Li DX, Cai YM, Pang HL (2015) Characterization, Identification and Application of Lactic Acid Bacteria Isolated from Forage Paddy Rice Silage. Plos One 10(3) doi:10.1371/journal.pone.0121967

40. Padmavathi T, Bhargavi R, Priyanka PR, Niranjan NR, Pavitra PV (2018) Screening of potential probiotic lactic acid bacteria and production of amylase and its partial purification. J Genet Eng Biotechnol 16(2):357-362. doi:10.1016/j.jgeb.2018.03.005

41. Qian BJ, Xing MZ, Cui L et al (2011) Antioxidant, antihypertensive, and immunomodulatory activities of peptide fractions from fermented skim milk with Lactobacillus delbrueckii ssp bulgaricus LB340. J Dairy Res 78(1):72-79. doi:10.1017/S0022029910000889

42. Rodriguez C, Medici M, Rodriguez AV, Mozzi F, de Valdez GF (2009) Prevention of chronic gastritis by fermented milks made with exopolysaccharide-producing Streptococcus thermophilus strains. J Dairy Sci 92(6):2423-2434. doi:10.3168/jds.2008-1724 
43. Saez GD, Hebert EM, Saavedra L, Zarate G (2017) Molecular identification and technological characterization of lactic acid bacteria isolated from fermented kidney beans flours (Phaseolus vulgaris L. and P. coccineus) in northwestern Argentina. Food Res Int 102:605-615.

doi:10.1016/j.foodres.2017.09.042

44. Saez GD, Saavedra L, Hebert EM, Zarate G (2018) Identification and biotechnological characterization of lactic acid bacteria isolated from chickpea sourdough in northwestern Argentina. Lwt-Food Science Technology 93:249-256. doi:10.1016/j.Iwt.2018.03.040

45. Shoukat S (2020) Potential anti-carcinogenic effect of probiotic and lactic acid bacteria in detoxification of benzo[a]pyrene: A review. Trends Food Sci Technol 99:450-459. doi:10.1016/j.tifs.2020.02.029

46. Soedamah-Muthu SS, Masset G, Verberne L, Geleijnse JM, Brunner EJ (2013) Consumption of dairy products and associations with incident diabetes, CHD and mortality in the Whitehall II study. Br J Nutr 109(4):718-726. doi:10.1017/S0007114512001845

47. Szutowska J, Gwiazdowska D (2021) Probiotic potential of lactic acid bacteria obtained from fermented curly kale juice (vol 203, pg 975, 2021). Arch Microbiol. doi:10.1007/s00203-021-02340-4

48. Unban K, Kanpiengjai A, Takata G, Uechi K, Lee WC, Khanongnuch C (2017) Amylolytic Enzymes Acquired from L-Lactic Acid Producing Enterococcus faecium K-1 and Improvement of Direct Lactic Acid Production from Cassava Starch. Appl Biochem Biotechnol 183(1):155-170. doi:10.1007/s12010-017-2436-1

49. Varoquaux P, Wiley RC (2017) Biological and Biochemical Changes in Minimally Processed Refrigerated Fruits and Vegetables. Minimally Processed Refrigerated Fruits and Vegetables, 2nd Edition:153-186 doi:10.1007/978-1-4939-7018-6_5

50. Wang S, Peng Q, Jia HM et al (2017) Prevention of Escherichia coli infection in broiler chickens with Lactobacillus plantarum B1. Poultry Sci 96(8):2576-2586. doi:10.3382/ps/pex061

\section{Figures}

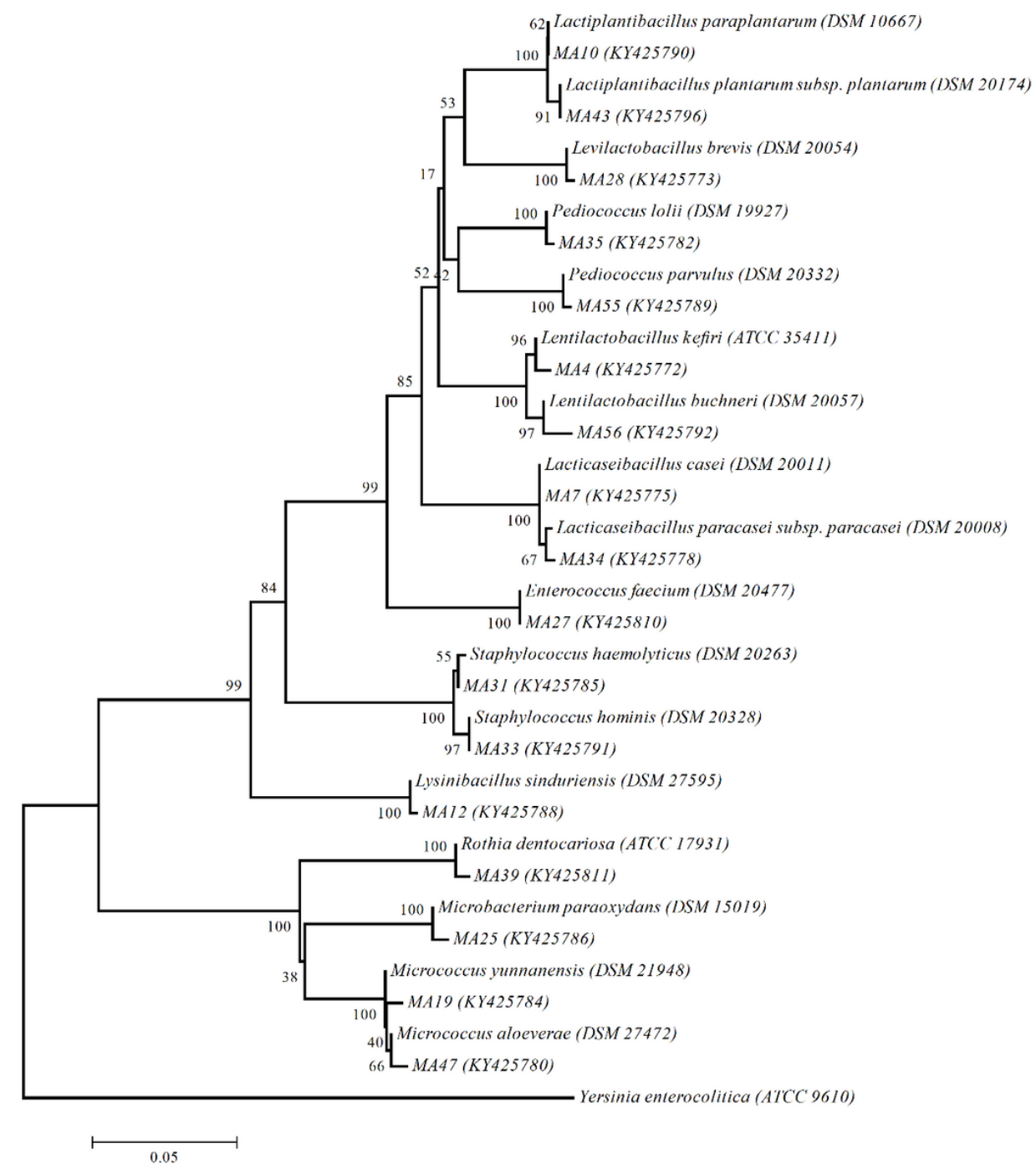

Figure 1

Page $10 / 12$ 
Neighbour joining phylogenetic tree based on 16S rRNA gene sequences of test strains and related type species. Yersinia enterocolitica ATCC 9610 was used as out-group. Bootstrap values based on 1000 replications are listed as percentages at branching points. The accession numbers are given in parentheses. The scale bar represented $0.5 \%$ divergence.

\section{$\begin{array}{lllllllllllllllllll}M & 1 & 2 & 3 & 4 & 5 & 6 & 7 & 8 & 9 & 10 & 11 & 12 & 13 & 14 & 15 & 16 & 17 & \mathrm{~N}\end{array}$}

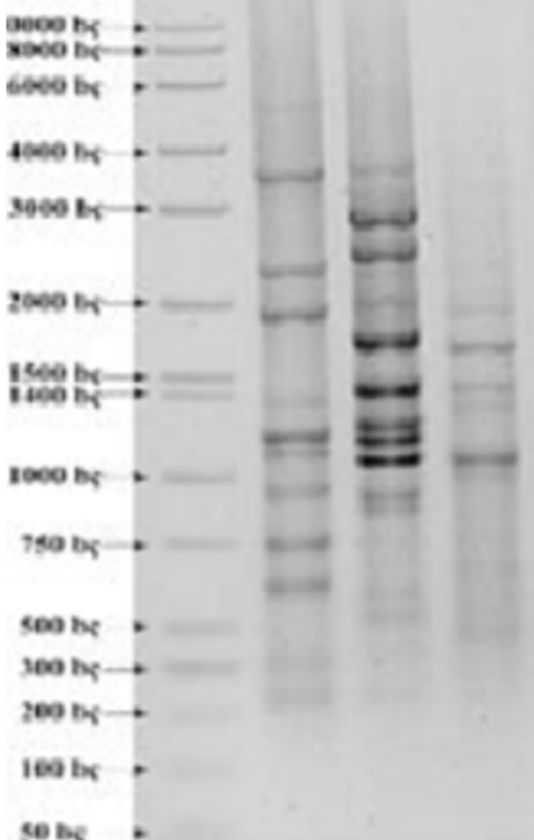

\section{Figure 2}

BOX-PCR profiles of isolates ( M:Marker, 1: MA4, 2: MA7, 3: MA10, 4: MA12, 5: MA19, 6: MA25, 7: MA27, 8: MA28, 9: MA31, 10: MA33, 11: MA34, 12: MA35, 13: MA39, 14: MA43, 15: MA47, 16: MA55, 17:MA56, N: Negative Control).
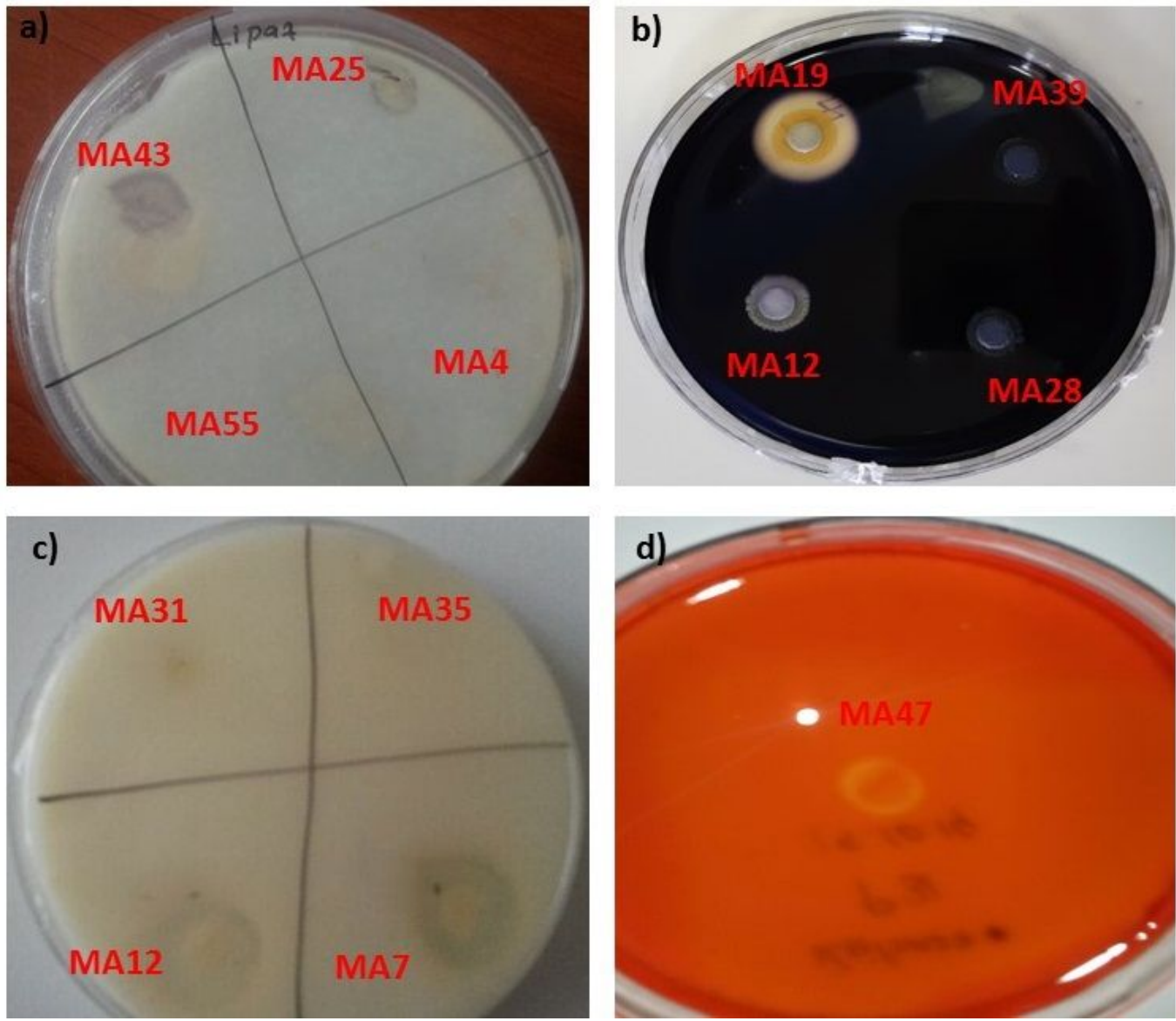
Figure 3

Screening biotechnological enzymes profiles of some isolates a) Petri image of lipase b) Petri image of amylase c) Petri image of protease d) Petri image of xylanase

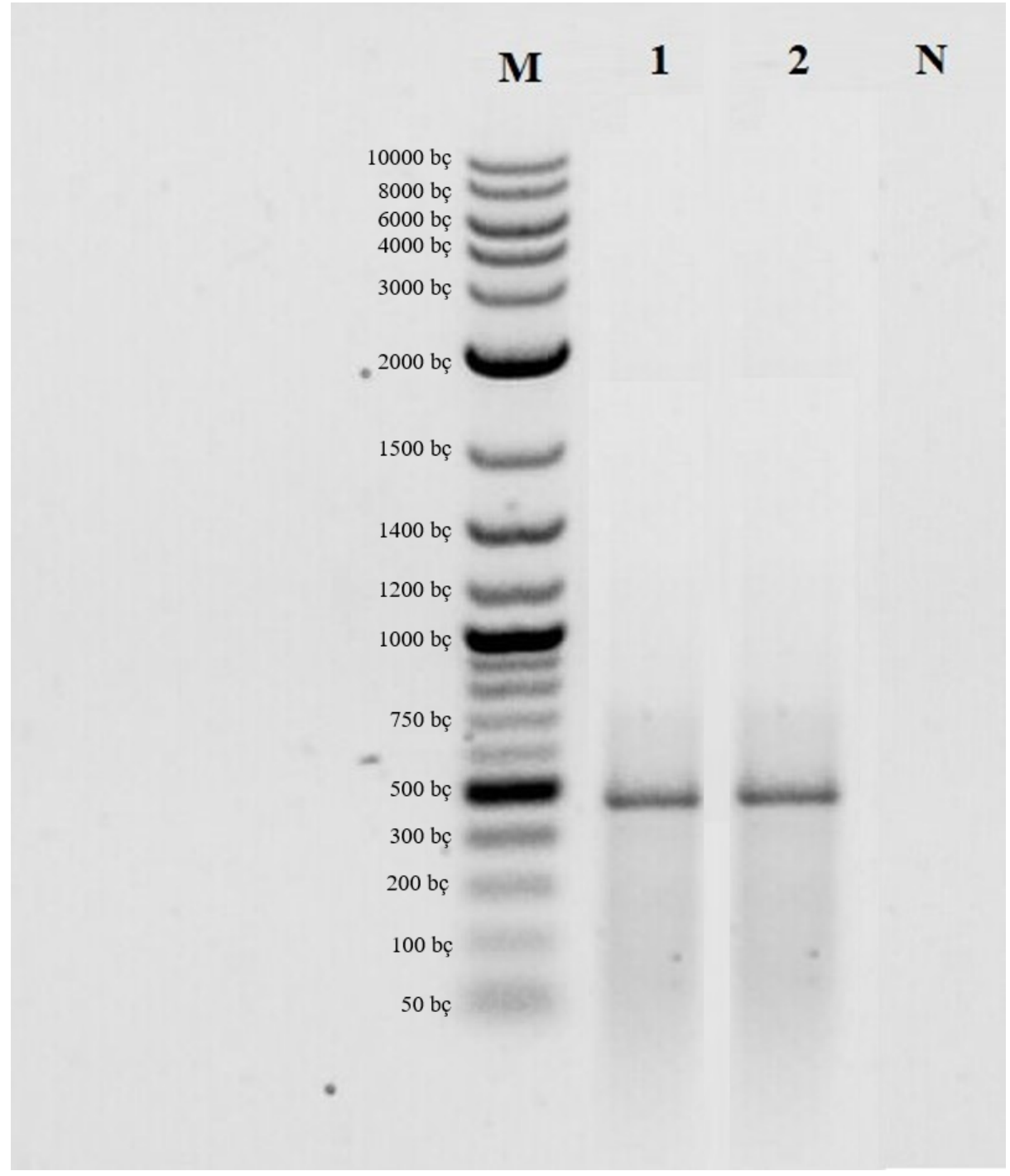

\section{Figure 4}

PCR analysis result of plantaricin genes. M: Marker, 1: Lactobacillus plantarum ATCC 8014, 2: MA43, 3: Negative Kontrol. 